\title{
Perspektif Islam Tentang Keadilan Ekonomi
}

\author{
Oleh : Syafaruddin Alwi
}

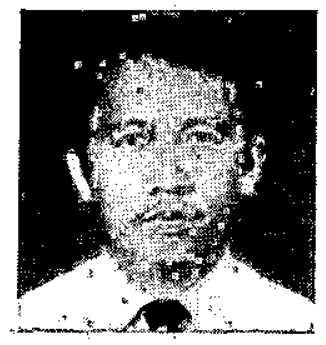

Syafaruddin Alwi, lahir di Baturaja pada tanggal 16 Januari 1947, adālah Lektor pada Fakultas Ekonomi Uii. Pernahi menjabat sebagai Dekan pada Fakultas tersebut 'selama tiga' periode yaitu tahun 1982-1988. Pada tahun 1973 s/d 1978 menjadi Ketua LPPM pada Fakultas yang sama sehingga sering melakukan kerja sama dalam pembinaan koperasi dengan berbagai Instansi baik swasta maupun pemerintah. 'Pada tahun 1986 mengikuti program Fellwship pada Australia National University di Canbera. Aktif mengikuti Seminar baik nasional maupun Internasional.

\section{Pengantar}

Keadilan dalam perspektif Islam' dalam konteks industrialisasi dapat diartikan sebagai keadilan dalam pemanfaatan sumber-sumber ekonomi dan keadilan dalam pendistribusian hāsilhasilnya. Islam tidaklah mengajarkan keadilan 'dalam ekonomi sebagai pendistribusian sumber dan hasil tanpa proses hukum-hukum ekonomi karena Islam tidak mengajarkan umatnya untuk menjadi peminta-minta. Hukum-hukum ekonomi di dalam Al-Qur'an menunjukkan prinsip-prinsip keseimbangan antar faktorfaktor yang kuat dan faktor-faktor yang lemah. Diciptakan adanya orang-orang yang kaya dan orang-orang yang miskin. Tetapi keduanya harus bekerjasama sehingga orang kaya memperoleh harta karena adanya orang miskin. Sebaliknya orang kaya harus memberi bagian kepada orang yang miskin karena itu memang hak-hak mereka.

Persoalannya sekarang dalam era industrialisasi kemungkinan munculnya pengangguran, merajalelanya kemiskinan dan ketimpangan pendapatan tetap saja mungkin menjadi (ketidakadilan ekonomi) sebagai akibat mẹnyempitnya lahan pertanian, investasi padat modal, motivasi kerja rendah, ketimpangan kekuatan perilaku ekonomi dsb. Bagaimana pandangan Islam tentang keadilan ekonomi itu dan konsep apa yang dapat diberikan Islam untuk mewujudkan keadilan ekonomi tersebut? Tulisan ini mencoba untuk memaparkan jawaban atas perntanyaan itu.

\section{Perspektif Ekonomi Islam}

Perspektif Ekonomi Islam saat ini sedang "diuji" melalui proses verifikasi dalam masyarakat, sejauh mana perspektif 
ini mampu menerangkan berbagại cara menghadapi dan mengatasi kebutuhan manusia yang semakin meningkat'dalam bentuk barang maupun jasa dan bagaimana mengatasi ketimpangan sosial yang terjadi. Tantangan yang dihadapi berarti berhubungan dengan masalah peningkatan produksi, peningkatan pendapatan masyarakat untuk meningkatkan daya beli (antara lain tingkat upah), sertapeningkatan motivasi untuk bekerja secara mandiri. Seorang sarjana Perancis' bernama Raymond Charles mengemukakan bahwa Perspektif Ekonomi Islam diwaktu yang akandatang akan menjadi Mazhab Ekonomi yang ke III karena perspektif ini mengajarkan proses produksi yang berkeadilan dan memperhatikan kepentingan pekerja. Selama ini para ahli agama dan ilmuan muslim telah banyak menerangkan pemikiran Islam tentang produksi, upah dan kerja tetapi hasil-hasil karya mereka belum memasyarakat secara' luas disebabkan beberapa asumsi:

1. Ada anggapan bahwa Ekonomi Islam sebagai suatu pemikiran, belum dapat diterapkan dalam suatu masyarakat yang hidup dinegara yang tidak menganut sistem negara Islam.

2. Pemikiran Ekonomi Islam belum terumus pada tahap teoritik, melainkan baru taraf ajaran yang bersifat normatif.

3. Perspektif Ekonomi Kontemporer dianggap paling mampu menjawab masalah-masalah ekonomi seperti kemiskinan, pengangguran dan ketimpangan dalam masyarakat dibandingkandengan konsepsi Ekonomi Islam yang populer hanya melalui zakat. Bank umum dengan praktek sistem bunga dianggap lebih aman dan resiko dibandingkan dengan konsep Islam melalui bank tanpa bunga yang mendasarkan pada basis persekutuan dan bagi hasil

Oleh sebab itu penegasan-penegasan pemikiran Islam dalam berbagai aspek ekonomi sangat perlu dilakukan agar asumsi-asumsi yang keliru seperti dimuka, tidak dikembangkan. Bahkan harus dapat diubah secara bertahap, bahwa perspektif Ekonomi Islam mampu memberi nafas baru padakehidupanekonomikontemporeryang lebih adil untuk menunjang tercapainya peningkatan produktivitas kerja masyarakat, penciptaan kesempatan kerja secara mandiri.

Dalam pembangunan ekonomi di negara-negara berkembang, masalah pengangguranmenimbulkan problem yang serius yaitu kemiskinan yang berlarut karena ketidakmampuan masyarakat memenuhi kebutuhan hidup secara mandiri: Tingkat pengangguran yang semakin bertambah jumlahnya, semakin kurang tertampung oleh perkembangan dan pertumbuhan kesempatankerja yang tersedia. Olehkarena itu pengangguran merupakan masalah yang rumit, bahkan lebih rumit dari padä masalah - pendistribusian pendapatan masyarakat. Masalah pengangguran pada hekekatnya bukanlah hanya bersangkutan dengan penyediaan lapangan kerja semata, melainkan berkaitan pula dengan masalah persepsi, motivasi sumber daya manusianya. Manusia yang memiliki persepsibăhwakerja adalah tanggung jawab pemerintah melalui penyediaan lapangan kerja dan investasi orang lain, akan berhadapan dengan kenyataan bahwa tersedianya lapangan kerja dan tuntutantuntutan yang menggiringnya ternyata tidak 
memberikan kesempatan kerja kepada setiap orang yang memiliki persepsi seperti itu. Tentu saja motivasi kerja yang didukung oleh perspesi seperti itu tidak mendukung perkembangan perekonomian masyarakat. Islam memberikan pemahaman yang jelas tentang kerja bagi setiap individu. Allah memberikan tugas kepada manusia untuk memakmurkan bumi, dengan memberikan modal berupa bumi dengan segala isi dan kandungannya (al-Baqarah : 29), untuk kemudian dimanfaatkan bagi kepentingan manusia itu sendiri. Upaya manusia secara mandiri berarti sangat diperlukan dan ini sangat dihargai oleh Allah. Dijadikannya manusia sebagai khalifah (al-Baqarah: 30 ), antara lain untuk membawa misi manusiá sebagai pimpinan dapat mengendalikan semua kekayaan alam dan manusia yang memerlukannya dengan nilai sebagai perwujudan ibadah kepadaNya (adDzariyat : 56). Islam memberikan konsep dasar penyelesaian masalah pengangguran dengan meletakkan peran keku'atan individu, yang dilengkapi dengan akal pikiran, untuk bekerja sesuai dengan keahlian yang dimiliki (Hud : 93).

Perintah untuk melakukan produksi terkandung didalam pengertian bahwanasib suatu kaum tidak akan berubah tanpa kaum itu sendiri berusaha merubah nasibnya (arRa'd:11).Perubahan nasibpadahakekatnya adalah perubahan taraf kehidupan setiap orang yang pada taraf yang lebih tinggi dari sebelumnya yang berdasarkan perspektif ekonomi modem diartikan sebagai nilai marginal yang diperoleh dari upaya yang telah dilakukan. Nilai guna barang yang semula tidak memiliki nilai ekonomis, karena dipindahkan letaknya menjadi bernilai ekonomis (place utility). Bemilai ekonomis karena diproses menjadi berubah bentuk (form utility). Itu semua merupakan upaya manusia untuk memperoleh pendapatan. Allah memberikan faktor pendukung atas upaya manusia untuk merubah taraf kehidupan tersebut dengan memberikan amanat agar manusia mau mengolah sumber daya alam yang telah diciptakanNya bagi kesejahteraan manusia itu sendiri.

Dengan latar belakang pemikiran Islam seperti yang telah diuraikan dimuka, makamakalah ini mencobamengemukakan secara spesifik pandangan İslam mengenai aspek-aspek yang sering dianggap sebagai sumber ketidak adilan dalam proses perekonomian kontemporer.

\section{Produksi dan Kepemilikan}

Produksi secara umum diartikan sebagai proses merubah sesuatu dari tidak' bermanfaat menjadi bermanfaat, dan tidak bemilai menjadi bemilai ekonomi. Barang menjadi bemilai ekonomi jika barang tersebut menimbulkan permintaan melalui tingkat harga yang berlaku. Demikian pula dengan jasa yang dihasilkan. Pelayanan (produksi jasa) seseorang, akan menciptakan nilai jika dengan pelayanan tersebut menimbulkan manfaat bagi orang lain. Ukuran kesejahteraan masyarakat adalah sejauh mana mereka dengan tingkat pendapatannya mampu mengkonsumsi produksi barang dàn jasa tersebut. Islam memberikan batasan berupa etika dalam menjalankan proses produksi dan proses mengkonsumsi. Etika ini pertama, adalah etika tauhid yaitu semua bahan baku yang digunakandalam proses produksi (industri), berasal dari Allah, dan oleh karena itu kepemilikan kekayaan alam walaupun 
dibenarkan secara individual, adalah terbatas. Terbatas dalam arti, kekayaan yang dimiliki itu adalah titipan (amanat) dari Allah sehingga tidak dikenal dalam Islam kepemilikan mutlak. Sebagian däri harta itu adalah milik orang lain (fakir miskin). Kepentingan kesejahteraan umum adalah lebih utama dari pada kepentingan pribadi. Kedua, etika tanggung jawab. Dalam menjalankan fungsi produksi tidak boleh menimbulkan kerusakan pada lingkungan dan hasil produksi haruslah menimbulkan nilai manfaat (ekonomi, kesehatan dsb), baik bagi produsen maupun konsumen. Oleh sebab itu, produksi minuman keras karena tidak menimbulkan manfaat bagi kedua belah pihak (kecuali produsen, yaitu manfaat ekonomi), dilarang diproduksi: Kedua etika tersebut, menentukan mutu barang yang akan diproduksi yang tunduk pada ketentuan Allah dan Sunnah.

'Pertumbuhan ekonómi menurut pandangan Klasik ditentukan oleh faktorfaktor kapital (sumber-sumber daya alam, barang-barang modal), penduduk (tenaga kerja), dan teknologi. Interaksi dari ketiganya melalui pengaturan sistem ekonomi kapitalis, pertumbuhan ekonomi dapat tercipta. Konsep ini dalam perjalannya kemudian yang diadopsi oleh sebagian besar negara-negara berkembang, ternyata tidak menjamin pendistribusian pendapatan masyarakat, walaupun terjadi kenáikan 'pertumbuhan' ekonomi yáng cukup tinggi. Hal ini disebabkan kepemilikan modal yang terpusat pada beberapa kekuatan dan tidak terjadi interaksi yang seimbang berdasarkan kerjasama yang saling menguntungkan antara pemilik dan pekerja. Islam mengajarkan bahwa Allah telah memberikan perangkat-perangkat produksi (tanah dankandungannya) termasuksistem pengolahannya (pemikiran ekonomi Iślam) yang dapat dipakai dalam usaha mencapai kesejahteraan ekonomi.

Faktor-faktor produksi yang mémungkinkan terselenggaranya proses produksi dalam Islam dikenal ada 4:

\section{a. Tanah}

Allah menciptakan bumi dengan. segala kandungannya adälah untuk kesejahteraan umat "manusia. Untuk mencapai kesejahteraan itu, tidaklainharuslah melalui proses perubahan tertentu yang disebut prosès produksi. Manusia diberi akal agar dapat mengembangkan ilmu pengetahuan sehingga dengan ilmu pengetahuan sehingga dengan ilmu pengetahuán yang dimiliki (teknologi dsb), manusia dapat melakukan penggalian sumber-sumber daya alam dan mengolahnya menjadi produk kebutuhan manusia. Dalam salah satu hadits dikemukakan: "Jika kamu ingin kebahagiaan didunia, haruslah dengan ilmu;jikakamumenginginkankebahagiaan diakhirat, haruslah dengan ilmu; dan jika kamu ingin keduanya, haruslah dengan ilmu.

Islam mengakui tanah sebagai suatu faktor produksi yang penting dan manusia wajib melakukan penggalian sumbersumber daya ini. Allah telah memberikan perangkat berupa hujan untuk membasahi tanah tandus sehingga dapat ditanami oleh manusia. Hal ini jelas tercermin didalam Al-Qur'an (As Sajadah, 27) yang menyatakan:

"Dan apakah mereka tidak memperhatikan bahwasanya Kami menghalau hujan ke bumi yang tandus, lalu Kami tumbuhkandengan 
air hujan tanam-tanaman yang dari padanyá dapat makan binatangbinatang ternak mereka dan mereka sendiri ...".

Dengan teknologi yang telah dikembangkan sedemikian rupa manusia telah mengembangkan sistem irigasi yang baik dan mampu menggali barang-barang tambang yang terkandung didalamnya untuk dijadikan bahan baku bagi produksi kita, tetapi Islam juga mengajarkan etika dalam cara melakukan proses produksi agar tidak merusak lingkungan. Faktor ini yang diabaikan oleh manusia sepanjang perjalanan perkembangan dunia sehingga Allah menilai, telah terjadi kerusakan dimuka bumi ini karena ulah manusia itu sendiri.

Kita harus menyadari, sebenarnya pemanfaatan tanah dan kandungannya, terutama sumber-sumber daya yang tidak dapat diperbaharui (unrenewable), merupakan tanggung jawab generasi sekkarang karena sumber-sumber daya tersebut akan diwariskan pula kepada generasi selanjutnya. Oleh karena itu peringatan Allah tentangkerusakan di bumi akibat ulah manusia dalam bentuk industrialisasi yang tidak memperhatikan pelestarian alam, haruslah dijadikan pelajaran.

\section{b. Tenaga Kerja}

Tenaga kerja merupakan faktoryang diakui oleh sistem ekonomi Islam bukan'hanya sebagai suatu jumilah yang besar yang diutamakan tetapi juga kualitastenagayang ditawarkan melalui permintaan dan penawaran tenaga kerja dan bentuk hubungan diantara pemilik dan pekerja.

\section{c. Modal}

Modal dalam ekonomi modem sangat ditentukan oleh tingkat bunga. Permintaan dan penawaran modal ditentukan seberapa besar tingkat bunga yang berlaku. Modal berasal dari tabungan yang memungkinkan terbentuknya barang-barang modal. Keynesian view memandang jika tingkat bunga tinggi maka tabungan yang terbentuk menjadi besar sehingga sumber modal pun menjadi besar. Tetapi konsep ini mengandung kelemahankarenajika tingkat bunga tinggi, maka investasi akan turun. Ini berarti kegiatan ekonomi akan mengalami penununan. Islam memandang modal yang terbentuk haruslah bebas dari bunga. Lalu persoalannya faktor apa yang menggerakan orang untuk menäbung dan menawarkan uangnya disektor ekonomi tanpa bunga?

Dalam kenyataan - tingkat bunga (harga uang) tidak selamanya merupakan faktor pendorong terbentuknya tabungan. Di dalam masyarakat terdapat berbagai motivasi termasuk motivasi mencari laba. Islam membenarkan laba sebagai insentif untuk menabung. Dalam kaitan ini hubungan perbankan dengan nasabah merupakan hubungan partnership dalam bentuk syirkah dan mudharrabah. Ekonomi Islam menggerakan faktor-faktor ekonomi . melalui proses kerjasama dan bukan ketergantungan.

Sistem bunga menimbulkan akibat hanya orang kuat (kaya) yang mampu menggunakan modal bank dalam perekonomian, sehingga penumpukan kekayaan akan terjadi hanya pada orang kaya. Sedangkan modal dalam Islam bersumber dari kesediaan orang kaya untuk berbagi hasil dengan orang miskin yang 
produktif melalui persekutuan dan bagi hasil. Sumber dana bagi unit-unit ekonomi dalam sistem Ekonomi Islam dapat pula berasal dari zakat (kekayaan). Zakat yang mampu dilembagakan, akan menghasilkan akumulasi kapital bagi pengusaha lemah dan akhimya akan menimbulkan proses multiplièr dilapisan bawah (masyarakat miskin). Al-Qur'an telah menjelaskan bahwa (Al Hasyr, 7):

"Supaya harta itu jangan hanya beredar diantara orang-orang kaya diantara kamu"

Dengan agar masyarakat pemilik uang mau memberikan sebagian kekayaannya bagi kegiatan produktif, Islam mengajarkan agar orang kaya mengendalikan tingkat konsumsi mereka pada taraf yang layak dan tidak berlebihlebihan. Hal ini dikemukakan dalam AlQur'an(Al An'am, 14), agarmanusiajangan hidup secara berlebih-lebihan karena Allah tidakmenyukai orang-orang yang berlebihlebihan:

\section{d. Organisasi}

Ciri organisasi didalam Ekonomi Islam sebagai faktor produksi adalah:

1) hubungan pemilik perusahaan dengan pekerja bukanlah hanya terbatas pada nilai ekonomi dalam bentuk upah dan kesejahteraan semata, melainkan terletak pada saling ketergantungan yang sama kuat. Bahwa orang kaya memperoleh kekayaan berkat kerjasamanya dengan orang-orang yang lemah.

2) keụntungan perusahaan menjadi urusan kedua belah pihak karena adanya persekutuan dan bagi hasil.
3) tanggung jawab manajerial pada organisasi pada hakekatnya juga tanggung jawab kepada Allah.

Mengenai kepemilikan kekayaan dalam Islam, Behesti (1989), mengemukakan tiga dasar kepemilikan dalam Islam yaitu:

a) manusia adalah pemilik bagi dirinya sendiri dan karenanyamenjadi pemilik bagi kerja yang dilakukannya.

b) bagian dari kerjanya memperoleh wujudnya yang nyatá dalam suatu barang.

c) manusia juga adalah pemilik alam bersama-sama dengan manusia sesamanya.

Dalam 'kaitannya dengan kepemilikan, kerja adalah proses pembentukan asalusul kepemilikan. Secara nalar Behesti mengemukakan bahwa seluruh umat manusia mempunyai jatah dalam alam. Namun demikian tindakan manusia untuk mengambil jatahnya itu diatur oleh norma-norma tertentu yang bertindak sebagai pelindung bagijatahumat manusia selebihnya. Semua aliran pemilikan selama ini menurut Behesti, selalu mengakui ketergantungan umat manusia : pada alam, 'dan masalah kepemilikan, jenis dan tingkatannya telah muncul secara bertahap dalam sejarah manusia.

Islam mengakui hal milik perseorangan dan hak milik masyarakat. Tetapi hak atas semua yang dimiliki individu dan masyarakat tersebut, menupakan milik Allah. "Hanya kepunyaan Allah jualah kerajaan langit dan bumi serta segala sesuatu diantara keduanya" (Al Maidah, 17).

Pandangan Islaḿtentang hak milik ini bukanlah merupakan penggabungan 
antara pandangan Sosialis yang mengakui 'kepentingan umum dan pandangan Kapitalis yang mengakui kepemilikan kekayaan individu secara mutlak, tetapi merupakan pandangan Islam yangoriginal. Manusia dalam Islam. diberi kewenangan oleh Allahuntukmengambilkekayaan alam secara benar, dan dengan memperhatikan etika Ketuhianan (segala sesuatu milik Allah), dan etika tanggung jawab baik kepada Allah maupun kepada sesama manusia. Norma-norma yang mengatur cara memperoleh kepemilikan ini khususnya bagi manusia terlihat didalam berbagai ayat didalam Al-Qur'an sebagai berikut:

(Al Baq̧arah, 188): "Dán janganlah kamu makan hartamu diantara kamú dengan. jalan yang bathil". dan

(Al An'am, 152): "Ianganiah kamu dekati hartaanakyatim, kecuali dengan carayang. lebih bermanfaat, hingga ia dewasa...".

Didalam kepemilikan itu terkandung suatu tanggung jawab bagi pemilik untuk menggunakan kekayaan yang dimiliki dengan menggunakan asas manfaat dalam tigá dimensi:

(1) dimensi individu atau rumah tangga Dalam hal ini penggunaan harta haruslah bermanfaat bagi pemilik dan keluarganya.

(2) dimensi masyarakat dan negara

Pemanfaatan harta untuk membantu pembentukan modal masyarakat dan ekonomi nasional.

(3) dimensi agama

Harta yang dimiliki bermanfaat pula bagi pengembangan agama.

Dalam usaha dan tanggung jawab sosial menanggulangi kemiskinan didalam masyarakat, pembayaran zakat secara sistematikkelembagaan, akan mempercepat pendistribusian kekayaan tersebut dikalangan fakir miskin. Persoalan yang dihadapi umát Islam sekarang' ini adalah, bagaimana menjadikan zakat sebagai sumber dana efektif bagi kebutuhan modal masyarakat lemah. Untuk menjamin kelangsungan proses ini, lembaga Bank Islam yang beroperasi dengan dasar bebas bunga, harus dikembangkan agar tidak menimbulkan proses yang paradoks di dalam masyarakat. Bank Islam dapat berfungsi sebagai Baitul Maal yang menyediaḱan Pos Dana Pelayanan Sosial khusus untuk dana yang berasal dari zakat.

Dengan demikian proses transfer pemilikan kekayaan selain melalui perdagangan diantara umat (mekanistis), juga melalui proses zakat. Zakat dapat menciptakan proses multiplier dalam ekonomi jika dana zakat yang ciberikan kepada kaum lemah tetapi mau bekerja (produktif), bilà mereka kemudian memperoleh keuntungan, maka keuntungan itu dapat pula dibayarkan sebagai zakat mereka melalui Bank Islam.-

\section{Pandangan Islạm tentang Kerja}

Bekerja merupakan suatu kewajiban bagi setiap individu yang sangat dihargai oleh Islam (al-Jum'ah, 10) dan memintaminta kepada orang lain merupakan upaya yang tak temilai (H.R. Baihaqi dan Abu Naim). Bekerja bagi setiap muslim adalah mutlak karena bagi Islam penciptaan nilai tambah sejalan dengan bertambahnya waktu, adalah wajib. Jika tidak manusia dianggap berada dalam kerugian (Al'Ashr). Nilai tambah yang diperoleh atau diciptakan' oleh setiap individu muslim yang memberikan efek positif terhadap kehidupan individu dan masyarakat merupakan amal saleh yang diterima Al- 
lah. BaniSärdidalam buku:The Economy of Divine Unity (Iqtishad at tauhidi), mengemukakan bahwa setiap orang akan melakukan tiga bentuk kerja.

\section{a. kerja manual}

Bani Sadr memberikan contoh beberapa imam di Iran bekerja dengan tangan mereka diladang agar memperoleh penghasilan tanpa memberatkanoranglain. Dalam sistem kerja adalah ibadah kepada Tuhan

\section{b. kerja administratif}

Kerjapadajenis ini dinyatakan setiap' orang harus mengambil bagian dalam kepemimpinan dan penyelesaian persoalanpersoalan kemasyarakatan dán negara. Dalam kaitan ini setiap orang memiliki tanggung jawab sebagaimana yang diamanatkan oleh Al-Quran.

\section{c. kerja inovatif}

Bentuk ini juga disebut sebagai bekerja kreatif. Seorang buruh dituntun untuk berinovasi melalui latihan dan pengalaman yang diperolehnya. Untuk dapat berinovasi setiap orang harus memiliki mental dasar yang kuat. Bani Sadr juga menegaskan bahwa hubungan antara Al-Khalik (Pencipta) dengan makhluk ciptaanNya (manusia), adalah berdasarkan atas kerja (ibadah). Al Qur'an menegaskan manusia dalam hụbungan dengan TuhanNya melakukan perniagaan. Demikian pula dalam hubungan sesama manusia. Hubungan antara sesamamanusia dalam lingkungannya berdasarkan atas kerja. Manusia menurut Al Qur'an tidak akan memperoleh sesuatu selain dari apa yang dikerjakannyà (QS. 23:39). Dimuka telah diterangkan bahwa perubahan kehidupan manusia hanya akan terjadi jika ada upaya (kerja) dari individu itu sendiri. Islam memberikan pandangan yang jelas tentang kerja yang dapat dijadikan dasar penyusunánkonsepmanajemenkerjadalam . suatu lingkungan organisasi. Pandangan pertama adalah, harus ada kerjasama yang saling mengisi, satu sama lain dengan memberikan penghargaan atas eksistensi setiap individu yang terlibat didalam kerjasama tersebut. Dasar diciptakannya manusiadalam jenjang derajatyang berbeda menurut Al Quran, tidak lain agar satu sama lain dapat saling mengisi. Penghargaan yang diberikan dapat berupa pengakuan akan nilai peran, dan diberikan dalam bentuk upah yang adil.

Dalam kaitan ini kebanggan sebagian besar negara berkembang bahwa mereka dapat menciptakan produk yang memiliki keunggulankompetitifkarena tingkat upah yang murah, sebenarnya sudah harus ditinggalkan. Konsepupah murah bukanlah perwujudan penghargaan yang seharusnya diberikan berdasarkan pandangan Islam. Itu adalah pandangan kaum kapitalis sesuai dengan perspektif klasik dan neo klasik. Kedua, harus ditegakkan prinsip bahwa tanggungjawab dalam melaksanakan suatu tugas harus diserahkan kepada individu sesuai dengan keahliannya. Tanggung jawăb itu dalam Islam bemilai ganda yaitu tanggung jawab struktural organisatoris dan tanggung jawab kepada Allah. Promosi jabatan dan atau penerimaan pegawai yang tidak berdasarkan pertimbangan keahlian tidak dianjurkan oleh Islam. Ketiga, dalạm melaksanakan pekerjaan hanuslah dalam waktu yang tidak meninggalkan kewajiban utama untuk mengingat Tuhan yaitu shalat. Waktu yang tersedia dikurangi dengan waktu untuk menjalankan shalat, 
merupakan waktu yang efektif bagi setiap muslim untuk bekerja dari total waktu yạng telah ditetapkańolehorganisasi atau industri dimana ia bekerja.

Ada beberapa faktorpendukung yang disediakanoleh Allah agarmanusia mampu melaksanakan pekerjaannya dalam upaya mencari rezki yaitu, faktor sumber daya alam, faktor akal, etika hubungan antar manusia dalam ekonomi dan kewajiban untuk bertanggung jawab. Sumber daya alam diakui oleh ekonomi modem sebagai faktor yang menentukan pertumbuhan ekonomi, selain faktor manusia dan teknologi. Todaro (1987), mengemukakan bahwa potensi pertumbuhan ekonomi suatu negara sebagian besar dipengaruhi oleh sumber daya pisik (tanah, mineral, dan bahan mentah lainnya), dan sumber daya manusia. Khusus mengenai sumber daya manusia ini meliputi tidak hanya mengenai jumlah penduduk saja tetapi juga mẹnyangkut, pandangan kebudayaan mereka, sikap terhadap pekerjaan dan keinginan untuk memperbaiki diri. Keinginan untuk merubah keadaan diri, sikap mencintai pekerjaan yang terwujud dalam pertanggung jawaban setiap individu di dalam Islam merupakan modal dasar yang penting. Kemiskinan berkaitan dengan ketidakmampuan orang merubah keadaan walaupun sumber-sumber daya pisik telah tersedia. Azhar Basyir (1978), mengemukakan bahwa orang akan dapat memenuhi kebutuhannya secara terhormat apabila ia bekerja dan berusaha: Dengan bekerja dan berusaha itu orang dapat memberikan sumbangannya kepada masyarakat. Berdiam diri atau menanti pertolongan orang lain dan mencukúpkan kebutuhan dengan jalan meminta-minta tidak dapat dibenarkan dari bahkan tercela. Islam memerintahkan kepada kita untuk mencari pada apa yang telah dianugerahkan Allah kepada kita kebahagiaan kampung akhirat, asal janganmelupakan kebahagiaan dan kenikmatan duniawi (Al Qashash, 77). Rasulullah telah banyak memberikan teladan mengenai bekerja ini. Sejak kecil Muhammad telah bekerja sebagai penggembala ' kambing. Bahkan diriwayatkan pula bahwa semua Nabi yang diutus, dia adalah penggembala kambing. Daud diutus, dia adalah penggembala, dan akupun diutus adàlah penggembala kambing keluargaku di Ajyat (sabda Rasulullah). Semua kita mengetahui bahwa beliau menggembala kambing milik Bani "Sa'ad bersama dengan saudara sesusuan beliau dan, kemudian menggembala kambing di Mekkah dengan upah tertentu. Perintah-perintah bagi umat Islam untuk bekerja dapat dibaca dari beberapa hadits sebagai berikut:

"Tidakada satumakananpunyang dimakan seseorang dari pada makanan dari hasil usaha sendiri. Sesungguhnya Nabi Allah Daud as juga makan dari hasil usahanya sendiri". (HR. Bukhari, Abu Daud). Pada hadits lain dikemukakan pula bahwa: "Jika hari kiamat datang, sedang ditangan salah seorang diantara kamu ada bibit pohon kurma, sekiranya masih sempat menanamkannya, maka tanamlah pohon kurma itu.

- Dengan basis pemikiran seperti itu Islam jelas telah meletakan dasar yang kuat bagi umatuntuk melakukan tugas produktif. Dalam pengertian ini maka setiáp muslim diharuskan menjadi inovator gunamembuat terobosan-terobosan baru dalam upaya penciptaan lapangan kerja bagi diri sendiri 
dan bagi orang lain.

Tantangan yang dihadapi oleh masyarakat dunia terutama di negara-negara berkembang termasuk Indonesia antaralain:
a. produktivitas rendah
b. tingkat pengangguran yang tinggi dan
c. kekurangan pekerjaan
d. standar hidup rendah.

3. Peningkatan Etos Kerja' dan Profesionalisme

Dari beberapa tantangan' tersebut masalah kekurangan pekerjaan disebabkan beberapa hal seperti lemahnya semangat kerja dan kekurangan keahlian dalam bidang yang sesuai dengan kemampuan. Akibatnya individu mengalami hambatan untuk memikirkan dan berbuat sesuai dengan keahliannya itu guna memanfaatkan sumber-sumber daya alam yang tersedia. Dalam konteks pembangunan saat ini masalah profesionalisme menjadi hal yang penting dan ini menyangkut peningkatan kualitas sumber daya manusia. Dalam teori manajemen módern, etos kerja bersangkutan dengan seberapa besa reward yang akan diperoleh setiaporang dari suatu lapangan pekerjaan yang tersedia. Etoskerja akan meningkat jika expected value atas hasil (pendapatan) dari suatu pekerjaan dianggap memuaskan. Sebaliknya profesionalisme menurut suatu keahlian dalam lapangan pekerjaan tertentu untuk memperoleh reward yang lebih tinggi. Dua sisi yang harus dipadukan guna memperoleh manfaat yang 'seimbang dan tingkat produktivitas yang tinggi. Etos kerja dikendalikan oleh motivasi kerja. Islam memandang proses ini sebagai ditentukan tidak hanya oleh epectancy terhadap reward semata tetapi ditentukan pula oleh persepsi bahwa bekerja dengan tangan sendiri untuk memenuhi kebutuhan hidup adalah utama. Kerja dalam Islam memiliki makna ganda. Disatu pihak kerja bemilai ibadah kepada Tuhan. Karenanya setiap manusia yang bekerjamemiliki tanggung jawablangsung kepada Allah. Dilain pihak kerja bemilai ekonomi bagi rumah tangga, dankerja juga . bernilai prestasi. Jika persepsi ini dikembangkan maka semangat kerja tidak hanya didorong oleh faktor perolehan ekonomi semata tetapi juga didorong oleh rasa berkewajiban berdasarkan perintah agama.

Hasil kerja adalah fungsi waktu sehingga manusia tidak dibenarkan untuk henya menunggu atau menerima apa adanya melainkan harus berbuat tanpa mengenal putus asa. Jadi Islam sangat menghargai kemandirian. Kemandirian merupakan salah satu ciri profesionalisme dalam anti luas.

Profesionalisme menuntut adanya spesialisasi baik lapangan pekerjaan maupun keahlian. Dalam kaitan ini, Azhar Basyir mengemukakan dalam bukunya: Garis BesarEkonomi Islam; bahwa adanya spesialisasi dalam berbagai lapangan kerja sebagai hal yanghukumnya fardhu kifayah, kita dapat menghubungkan dengan ajaran tentang keharusan adanya kerjasama kemanusiaan. Dalam berspesialișasi hendaklah atas dasaruntuk dapat memenuhi kebutuhan hidup umat manusia yang beraneka ragam dan macamnya dalam rangka memenuhi perintah mewujudkan kerjasama kemanusiaan, yang demikian akan bemilai keagamaan, bukan sematamata untuk mendapatkan penghasilan duniawi.

Pernyataan seperti diatas 
menunjukkan adanya suatu keyakinan dalam Islam bahwa spesialisasi menuntut diserahkannya pekerjạan pada ahlinya (profesional). Hadits riwayat Bukhari memperkuatkeyakinan itu bahwa:"Apabila urusan diserahkan kepada bukan ahlinya, maka tunggulah saat kehancurannya".

Profesionalisme dalam Islam selain mensyaratkan adanya spesialisasi keahlian, juga mengakui adanya sifat terstruktur dalam pekerjaan dan pendapatan. AlQur'an (Al Ahqaf, 19), mengajarkan bahwa manusia yang terlibat didalam kerjasama itu masing-masing memiliki tingkatan menurut apa yang telah mereka kerjakan dan agar Allah, memenuhi balasan pekerjaan-pekerjaan mereka, sedikitpun mereka tidak teraniaya.

Salahsatu pekerjaan yang dihalalkan oleh Islam adalah perdagangan. Dalam perdagangan Islam cara melakukan perdagangan sangatmenjadi perhatian yaitu jangan dengan cara yạng curang. Curang baik dalam takaran, maupun curang dalam pembayaran (hutang), tidaklah dibenarkan. Dalam Al-Qur'an dijelaskan bahwa perdagangan dihalalkan "tetapi riba diharamkan. Perdagangan mengandung tantangan (resiko), tetapi tantangan yang demikian itu diperlukan bagi setiap orang karena Islam menghargai upaya. Sedangkan riba tidaklah mengandung resiko bagi pemilik modal. Berarti mengajarkan keadilandalam proses ekonomi dalam usaha seseorang memperoleh keuntungan.

\section{Hubungan Perburuhan dan Upah}

Interaksi yang baik antara pemilik perusahaan atau pemilik tanah buruh atau karyawan yang bekkerja baik disektor pertanian, maupun industri, akan menciptakan iklim kerja yang kondusif. Elton Mayo, telah mengembangkan pemikiran yang mendasarkan pada asumsi bahwa produktivitas kerja seseorang tidak hanya ditentukan oleh tingkat upah yang diterima oleh seorang pekerja, melainkan ditentukan oleh hubungan kemanusiaan (human relationship) antara manajer dan pekerjanya itu. Test yang dilakukaribahwa orang yang bekerja dengan motivasi tinggi tidak terpengaruh oleh faktor lain seperti cahaya, upah dsb. Motivasi yang tinggi itu, ternyata dipengaruhi pula oleh pola hubungan antara manajer dan karyawan dalam suatu organisasi ekonomi.'Sejak itulah (1930), ilmu Hubungan Antar Manusia mulai berkembang.

Pandangan Islam dalam konteks hubungan perburuhan sebenamya sangat mendasár bahwa hubungan antara pemilik modal (orang kuat), dengan pekerja (orang lemah), adalah hubungan yang saling memperkuat. Karena; orang kaya memperoleh rezki berkat kerjasamanya dengan kaum yang lemah. Oleh sebab itu pengembanganpemilikan saham padataraf perusahaan telah berkembang, sebenamya yang pertama kali diberi kesempatan membeli saham perusahaan adalah para karyawannya. Kemudian dasar hubungan yang terbentuk juga berlandaskan ajaran bahwa muslim itu bersaudara. Perbedaan diantara manusia bukan atas dasar kedudukan tetapi atas dasar takwanya kepada Tuhan.

Perselisihan antara tenaga kerja dan majikan seperti yang selama ini sering terjadi disebabkan hubungan yang tidak harmonis, dan majikan membayar pada tingkat upah yang dianggap masih dibawah standar yang ditetapkan oleh Pemerintah. 
Islam tidak mengenal pengisapan buruh olehmajikan, tetapijuga tidakmengabaikan adanya kelas kapitalis. Islam mengakui adanya perbedaan kemampuan yang mengakibatkan timbulnya perbedaan imbalan material (upah, gaji dan insentif lainnya) (An Nisa', 33). Dengan hubungan yang didasarkan kepada saling ketergantungan satu sama lain maka musyawarah dalam Islam sangat dianjurkan untukmerigatasi konflik buruh danmajikan.

Upah sebagai cara pemberian harga tenagakerjadalam Islam harus disegerakan dan tidak boleh ditahan. "Upah seorang pekerja harus dibayarkan sebelum keringatnya kering". Islam juga sangat. memperhatikan tingkat kesejahteraan para pekerja seperti riwayat yang bersumber dari Muhallah dari Ibn Hazam:"Kewajiban para majikan mempekerjakan mereka denganpekerjaanyang dapat dilakukannya dengan mudah.Janganlah mempekerjakan mereka sedemikian rupa sehingga merugikan kesehatannya".

Berdasarkan keterangan itu jelaslah, imbalan atas jerih payah buruh yang dibayarkan kepada buruh haruslah dengan kriteria:

a. ketetapan waktu pembayaran upah

b. keseimbangan tenaga dan volume kerja

c. tidak boleh menahan upah tanpa alasan yang jelas.:

Ditinjau dari kedudukan buruh.-Islam memandang buruh harus menghormati majikannya dan buruh harus bertangging jawab atas kualitas pekerjaannya. Dalam salah satu hadits disebutkan (sumber Ibn Majah): "Pendapatan terbaik adalah pendapatan seorang pekerja yang melakukän pekerjaannya dengan hati-hati, dan ia hormat kepada majikannya.

Islam jugamengutuk penyelewengan seorang pekerja terhadap harta majikan sebagaimana dijelaskan oleh sebuah hadits (Bukhari): "Nabiberdiridiantarakami dan berbicara mengenai ketidakjujuran, dia menyatakan jahatnya perbuatan itu .......".

Dengan demikian hubungan perburuhan dalam Islam jika diterapkan secara baik akan memberikan makna yang harmonis bagi kepentingan kedua belah pihak dan kepentingan perusahaan secara keseluruhan.

\section{Penutup}

Kesimpulan dari uraian dimuka, bahwa Islam tentang keadilan ekonomi, bukan sajamengajarkantentang bagaimana membagi hasil pembangunan secaramerata tetapi juga keadilan dalam prose pembangunan ekonomi itu sendiri. Dalam proses tersebut prinsip keseimbangan tampak dengan jelas mulai dari faktor kepemilikan, proses produksi, penggunaan modal, pembayaran upah, hubungan antar manusia sampai kepada transaksi perdagangan. Walaupun prinsip-prinsip itu masih dalam taraf normatif tetapi jika pelaku-pelaku ekonomi menerapkannya, atas izin Allah, akan tercapai keadilan ekonomi yang didambakan. 
Acuan

Aboolhasan, Bani. Sadr (1985), Buruh, Kerja dan Islam, Salahuddin Press, Yogyakarta.

Afzal-Ur-Rahman (1991),DoktrinEkonomi Islam, Jilid I, Dewan Bahasa dan Pustaka, Kualalumpur.
Ahmad Azhar Basyir (1981), Garis Besar Ekonomi Isiam, BPEE, Yogyakarta. Behesti (1988), Kepemilikan Dalam Islam, Pustaka Hidayah, Jakarta.

Michel P. Todaro (1987), Pembangunan Ekonomi di Dunia Ketiga, Penerbit Ghalia Indonesia. 